\title{
Obituaries
}

Obituaries should be submitted by email to Kate Maynard at k.maynard@nature.com.

All submitted obituaries should be 350 words maximum in length (apart from obituaries for past presidents of the BDA where the length should be $700-800$ words).

Content of the obituary is down to the individual author, and the approval of the family should be given for the obituary prior

to submission to the $B D J$.

\section{JERRY WHITE}

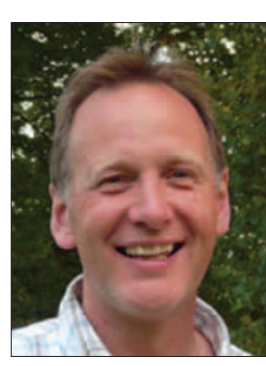

James Jeremy

White, born 22

August 1961,

passed away peace-

fully on 9 August

2010. He collapsed

whilst riding his

bike in the Peak

District and despite

strenuous efforts from passersby and medical personnel, he died tragically young just short of his 49th birthday.

Jerry grew up in Coleraine, County Londonderry, Northern Ireland, attending Coleraine Academical Institution where he was Deputy Head Boy and represented the Irish Schools International Swimming Team. He came to Sheffield to study dentistry at the Charles Clifford Dental Hospital leaving a lasting impression on all he met. He was 'larger than life' and his infectious good humour and easy banter characterised his undergraduate years. It was in those golden days that he first met his wife to be, Saskia, truly the love of his life.

Jerry moved into general practice in Doncaster where he remained his entire working life. The many moving testimonials from his patients and staff show how much his immense professionalism, care and compassion were valued. Jerry joined the Doncaster Local Dental Committee in 2004, becoming Chairman in 2007, enthusiastically performing roles well beyond his duties and in a manner that only Jerry could, especially with the introduction of the new NHS dental contract.

Away from his profession, his interests included walking, tennis, cycling, running and swimming - his ambition was always to complete some great open water swim. His passion though was spending time with his family, Saskia, Rachel and Adam, their relatives and many friends where laughter and 'craic' were ever present. He was a great entertainer and was never happier than in his role as host, telling jokes and stories, his wit and repartee second to none. He was, however, a great listener, and he always had time and empathy for anyone, any time.

His tragic, untimely death has shocked patients, friends and colleagues alike. However, above all, he will be missed most by Saskia and his children; he was the quintessential family man. What better epitaph than to say Jerry touched the lives of all who knew him and though he will be greatly missed, we are all the richer in spirit for having known him.

\section{G. T. Craig, S. J. Bickerton}

\section{IAN HERD}

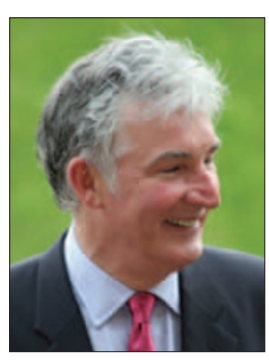

Ian Forbes Herd died at home in October 2011 after a lengthy illness. Ian was born in Edinburgh on 15 April 1954. The family moved to Falkirk where Ian and his younger brother Douglas were educated at Wallacestone Primary School and Falkirk High School.

In 1972 Ian attended Edinburgh University Dental School, graduating in 1977. During his time at Edinburgh he met and married Ann. Ian joined Jimmy Kinniburgh in practice at Grangemouth where he remained all of his working life.
At the same time Ian was taking a leading role first in Polmont Rotaract and then in Grangemouth Round Table. By this time two children, Kirsty and Christopher, had arrived and he took great delight in them whilst managing to pursue his two other pastimes, golf and cars.

In the space of two weeks in 1998 Ian's life changed dramatically when his partner Jimmy died and Ian had an accident which broke his ankle. After a long struggle this resulted in the loss of Ian's ankle and although this changed things he did not allow it to stop his passion for life.

Ian was the visiting dentist at Polmont Young Offenders Institute for 25 years. He became chairman of the Stirling and Clackmannan section of the BDA and then the lure of dental politics arrived and he became chairman of the LDC, ADC and area clinical forum of Forth Valley Health Board.

He found time to complete a clinical attachment in orthodontics and become a vocational trainer. Such was the influence on training that the local health board inaugurated a prize, 'The Herd Medal', in honour of Ian and his brother, who predeceased him, to be awarded for a case presentation to a VDP and also to a DCP for the best performance in the national exam.

Ian and his partner Alistair Bryden had recently extended their premises to include a state of the art decontamination unit and were rightly proud of their achievement.

Ian will be missed by his colleagues and the patients whom he cared for over 30 years. He leaves his wife Ann and children Kirsty and Christopher.

C. M. Ormond 